\title{
PENGARUH STARTER EXPERIMENT APPROACH (SEA) TERHADAP HASIL BELAJAR IPA
}

\author{
Ni Md. Risa Mei Indiarini' ${ }^{1}$, Gd. Wira Bayu ${ }^{2}$ \\ 1,2,3 Jurusan Pendidikan Guru Sekolah Dasar \\ Universitas Pendidikan Ganesha \\ Singaraja, Indonesia \\ e-mail: risaid98@yahoo.com ${ }^{1}$, wira.bayu@undiksha.ac.id ${ }^{3}$
}

\begin{abstract}
Abstrak
Penelitian ini bertujuan untuk mengetahui pengaruh Starter Experiment Approach (SEA) terhadap Hasil belajar IPA siswa kelas V SD Gugus II Kecamatan Banjar Kabupaten Buleleng.Populasi dalam penelitian ini adalah seluruh siswa kelas V di Gugus II Kecamatan Banjar Kabupaten Buleleng.Sampel dalam penelitian ini sebanyak 2 kelas, yaitu kelas eksperimen dan kelas kontrol yang terdiri dari 46 orang.Pengumpulan data dilakukan dengan menggunakan metode tes.Data yang diperoleh dianalisis menggunakan statistik deskriptif dan statistik inferensial, dengan uji-t. Berdasarkan analisis data dengan uji-t, diperoleh nilai thitung sebesar 6,14 dan diperoleh nilai ttabel sebesar 2,07.Sehingga thitung $(6,14)>$ ttabel $(2,07)$. Hal ini menandakan bahwa terdapat pengaruh yang signifikan hasil belajar IPA antara kelompok siswa yang dibelajarkan dengan menggunakan Starter Experiment Approach (SEA) dan kelompok siswa yang dibelajarkan tidak menggunakan Starter Experiment Approach (SEA) pada siswa kelas V SD Gugus II Kecamatan Banjar Kabupaten Buleleng tahun pelajaran 2017/2018. Ini berarti bahwa Starter Experiment Approach (SEA) berpengaruh secara signifikan terhadap hasil belajar IPA siswa kelas V SD di Gugus II Kecamatan Banjar Kabupaten Buleleng Tahun Pelajaran 2017/2018.
\end{abstract}

Kata-kata kunci: starter experiment approach (sea), hasil belajar, IPA.

\begin{abstract}
This study aimed for investigating the effect of Starter Experiment Approach (SEA) on Science's result of 5th grade students in 2nd region of Banjar district, Buleleng regency. The population in this study were all 5th grade students in 2nd region of Banjar district, Buleleng regency. The sample in this study were 2 classes, 46 people for experimental and control group. The data was gathered by using test, the data were analyzed by using descriptive statistic, inferential statistic and T-Test. Based on T-Test, the value of ttestwas 6,14 and ttablewas 2,07 . Thus, ttest $(6,14)>$ ttable $(2,07)$. It was assumed that there was a significant different between the group with Starter Experiment Approach (SEA) and the group which was not using Starter Experiment Approach (SEA) to 5th grade students in 2nd region of Banjar district, Buleleng regency year 2017/2018. It could be concluded that Starter Experiment Approach (SEA) had significant effect for Science's result of 5 th grade students in 2nd region of Banjar district, Buleleng regency year 2017/2018
\end{abstract}

Keywords : starter experiment approach (sea), outcomes, science 


\section{Pendahuluan}

IPA atau science merupakan ilmu tentang alam. Ilmu yang mempelajari peristiwaperistiwa yang terjadi di alam ini. Berdasarkan karakteristiknya, IPA berhubungan dengan cara mencari tahu tentang alam secara sistematis, sehingga IPA bukan penguasaan kumpulan pengetahuan yang berupa fakta-fakta, konsep-konsep, atau prinsip-prinsip saja tetapi juga merupakan suatu proses penemuan Samatowa (2010:3). Proses pembelajaran IPA hendaknya menekankan pada pemberian pengalaman langsung untuk mengembangkan kompetensi agar dapat memahami alam sekitar secara alamiah.

Hakikat IPA secara garis besar yaitu IPA sebagai produk dan IPA sebagai proses, dan IPA sebagai sikap imiah. Bundu (2006:11) mengungkapkan bahwa "IPA sebagai produk merupakan kumpulan hasil kegiatan empirik dan kegiatan analitik yang dilakukan para ilmuan selama berabad-abad".Bentuk IPA sebagai produk berupa fakta-fakta, konsep-konsep, prinsipprinsip, hukum, dan teori. IPA sebagai proses yaitu bagaimana mengumpulkan fakta-fakta dan bagaimana menghubungkan fakta-fakta untuk menginterpretasikannya. Proses IPA merupakan prosedur empirik dan analitik dalam usaha menghasilkan produk IPA.IPA seabagai sikap ilmiah adalah sikap yang dimiliki para ilmuan dalam mencari dan mengembangkan pengetahuan yang baru.

Pembelajaran IPA di sekolah dasar diharapkan dapat menjadi wahana bagi siswa untuk mempelajari diri sendiri dan alam sekitarnya.Disamping itu pembelajaran IPA hendaknya dirancang sedemikian rupa sehingga siswa merasa senang dan tidak merasa bosan dalam mengikuti pembelajaran. Selain itu pembelajaran lebih menekankan kepada keaktifan siswa baik secara fisik maupun mental serta menekankan pada proses dalam mengikuti pembelajaran. Pembelajaran yang dirancang agar selalu memberikan kesempatan bagi siswa untuk memanfaatkan semua inderanya untuk belajar dengan mengaktifkan komunikasi, kerja sama dengan siswa yang lain. Hal tersebut akan mempermudah dan mempercepat siswa memahami sesuatu, meningkatkan keterampilan siswa, serta meningkatkan sikap positif siswa terhadap mata pelajaran IPA.

Namun pada kenyataannya di sekolah dasar, termasuk di SD Gugus II Kecamatan Banjar, Kabupaten Buleleng hasil belajar IPA masih belum sesuai harapan. Berdasarkan hasil observasi yang dilaksanakan pada tanggal 2 Januari 2018 di kelas $\mathrm{V}$, dinyatakan bahwa di dalam proses pembelajaran guru belum menerapkan pendekatan pembelajaran yang inovatif. Pendekatan pembelajaran Inovatif yang dimaksud yaitu pendekatan pembelajaran yang lebih berpusat pada student centered. Artinya pendekatan pembelajaran yang lebih menekankan peluang kepada siswa untuk mengkonstruksi pengetahuan secara mandiri (self directed) dan dimediasi oleh teman sebaya. Hal ini akan berdampak pada hasil belajar siswa.

Menurut Winkel, 1996 (dalam Purwanto, 2009:45) menyatakan bahwa "hasil belajar merupakan perubahan yang mengakibatkan manusia berubah dalam sikap dan tingkah lakunya". Keberhasilan dalam proses pembelajaran di sekolah dapat dilihat dari tingkat pemahaman, penguasaan materi serta prestasi belajar siswa. Belajar merupakan proses dalam diri individu yang berinteraksi dengan lingkungan untuk mendapatkan perubahan dalam perilakunya. Belajar adalah proses untuk membuat perubahan dalam diri siswa dengan cara berinteraksi dengan lingkungan untuk mendapatkan perubahan dalam aspek kognitif, afektif, dan psikomotor.

Data hasil belajar pada siswa SD Gugus II Kecamatan Banjar Kabupaten Buleleng, pada ulangan tengah semester ganjil masih rendah. Hal ini ditunjukkan dari nilai Ulangan Tengah Semester (UTS) kelas V untuk mata pelajaran IPA, dilihat dari tabel 1.1 sebagai berikut. 
Tabel 1. Pencapaian KKM Skor Ulangan Tengah Semester (UTS) Siswa Kelas V SD di Gugus II Kecamatan Banjar Tahun Pelajaran 2017/2018

\begin{tabular}{ccccccc} 
& \multirow{2}{*}{ Nama Sekokah } & KKM & $\begin{array}{c}\text { Jumlah } \\
\text { Siswa }\end{array}$ & & $\begin{array}{c}\text { Jumlah Siswa Capai } \\
\text { KKM }\end{array}$ & \multicolumn{2}{c}{$\begin{array}{c}\text { Jumlah Siswa } \\
\text { Tidak Capai KKM }\end{array}$} \\
\cline { 6 - 7 } & & & Siswa & $\%$ & Siswa & $\%$ \\
\hline $\begin{array}{c}\text { SD Negeri 1 } \\
\text { Tigawasa }\end{array}$ & 65 & 31 & 6 & 0,19 & 25 & 0,81 \\
\hline $\begin{array}{c}\text { SD Negeri 2 } \\
\text { Tigawasa }\end{array}$ & 66 & 32 & 3 & 0,09 & 29 & 0,91 \\
\hline $\begin{array}{c}\text { SD Negeri 4 } \\
\text { Temukus }\end{array}$ & 65 & 23 & 2 & 0,09 & 21 & 0,91 \\
\hline $\begin{array}{c}\text { SD Negeri 5 } \\
\text { Temukus }\end{array}$ & 67 & 23 & 3 & 0,13 & 20 & 0,87 \\
\hline Jumlah & & $\mathbf{1 0 9}$ & $\mathbf{1 4}$ & $\mathbf{0 , 5}$ & $\mathbf{9 5}$ & $\mathbf{3 , 5}$ \\
\hline Rata-Rata & & & & $\mathbf{0 , 1 2}$ & & $\mathbf{0 , 8 8}$
\end{tabular}

(Sumber: Dokumen guru kelas V di Gugus II Kecamatan Banjar, 2018)

Berdasarkan hasil observasi yang tertera pada tabel di atas, dapat diketahui bahwa pencapaian hasil belajar IPA yang mencapai KKM di SD Negeri 1 Tigawasa sebanyak 0,19 sedangkan siswa yang tidak mencapai KKM sebesar 0,81. Untuk hasil belajar IPA yang mencapai KKM di SD Negeri 2 Tigawasa sebanyak 0,09 sedangkan siswa yang tidak mencapai KKM sebesar 0,91. Kemudian untuk hasil belajar IPA yang mencapai KKM di SD Negeri 4 Temukus sebanyak 0,09 sedangkan siswa yang tidak mencapai KKM sebesar 0,91. Selanjutnya untuk hasil belajar IPA yang mencapai KKM di SD Negeri 5 Temukus sebanyak 0,13 sedangkan siswa yang tidak mencapai KKM sebesar 0,87. Dari pemaparan di atas maka dapat disimpulkan bahwa pencapaian hasil belajar IPA di Gugus II Kecamatan Banjar Kabupaten Buleleng yang baru mencapai KKM sebesar 0,12 persen, sedangkan yang belum mencapai KKM sebesar 0,88 persen. Namun setelah dibandingkan ternyata didapatkan bahwa siswa yang belum mencapai KKM lebih tinggi persentasenya daripada siswa yang sudah mencapai KKM.

Pencapaian nilai IPA siswa menunjukkan bahwa sebagian besar siswa memperoleh nilai yang rendah. Rendahnya hasil belajar tersebut dapat dipengaruhi oleh beberapa faktor. Diduga salah satu faktor penting yang dapat mempengaruhi hasil belajar siswa adalah pendekatan pembelajaran yang diterapkan oleh guru.

Berdasarkan dengan hasil wawancara pada saat proses pembelajaran IPA yang dilakukan kepada salah seorang guru kelas V di Gugus II Kecamatan Banjar, Kabupaten Buleleng pada tanggal 2 Januari 2018, maka ditemukanlah permasalahan yang terdapat di dalam kelas. Permasalahan-permasalahan tersebut, antara lain: (1) guru kurang bisa mengkondisikan kelas, dikarenakan guru tidak menggunakan pendekatan pembel;ajaran yang lebih menyenangkan, sehingga siswa bisa fokus dalam mengikuti pembelajaran. Pengkondisian kelas sangat penting dalam proses pembelajaran, (2) sumber belajar siswa hanya buku pelajaran. Guru hanya menggunakan buku sebagai sumber belajar tanpa memanfaatkan sumber belajar lainnya, seperti menggunakan bantuan percobaan dalam pembelajaran IPA. Guru merasa memiliki banyak kesibukan, sehingga tidak sempat menggunakan sumber-sumber belajar lainnya, (3) guru jarang menerapkan diskusi kelompok. Kegiatan diskusi kelompok jarang dilakukan oleh guru karena guru menganggap kegiatan diskusi kelompok sulit untuk mengatur siswa, sehingga siswa jarang melakukan proses bertukar pikiran dengan siswa lainnya. Hal ini mengakibatkan siswa yang kurang mampu akan tertinggal, sedangkan siswa yang pintar akan jauh meninggalkan siswa yang kurang mampu (4) guru jarang menerapkan percobaan IPA di dalam kelas karena siswa masih ceroboh, disamping itu pula fasilitas yang terdapat di sekolah tidak memadai. Percobaan itu sangat cocok diterapkan pada diskusi kelompok . 
Berdasarkan hal tersebut perlu dicarikan solusi agar pembelajaran yang dilaksanakan dapat memberikan hasil belajar yang optimal. Salah satunya dengan penerapan pendekatan pembelajaran yang tepat. Pendekatan pembelajaran yang mampu memberikan kesempatan kepada siswa untuk membangun pengetahuan berdasarkan pengalaman nyata siswa dan memotivasi siswa untuk aktif dalam pembelajaran. Terkait dengan itu, maka cara terbaik bagi anak didik untuk mempelajari IPA terhadap hasil belajarnya adalah dengan Starter Experiment Approach (SEA).

Starter Experiment Approach (SEA) merupakan pendekatan pembelajaran yang berhubungan dengan karakteristik siswa, dimana pada pendekatan pembelajaran ini siswa menjadi lebih aktif untuk memecahkan permasalahan yang diberikan oleh guru. "Starter Experiment Approach (SEA) merupakan pendekatan pembelajaran komprehensif dalam pembelajaran sains. Starter Experiment Approach (SEA) sebagai sebuah pendekatan dalam pembelajaran sains berorientasi kepada proses bagaimana siswa dapat menemukan konsepkonsep sains yang sedang dipelajari oleh siswa" (Suastra, 2013:150). Kelebihan Starter Experiment Approach (SEA) ini adalah untuk meningkatkan aktivitas dan kreatifitas siswa, dan membiasakan siswa berpikir dan bertindak ilmiah, serta memperlihatkan adanya keterkaitan IPA dengan lingkungan.

Berdasarkan hal tersebut, pembelajaran dengan pendekatan Starter Eksperimen, Starter Experiment Approach (SEA) memiliki pengaruh terhadap hasil belajar siswa. Namun, besarnya pengaruh pembelajaran dengan Starter Experiment Approach (SEA) belum dapat diketahui secara pasti.Berdasarkan pemaparan tersebut, maka dilakukan penelitian yang berjudul "Pengaruh Starter Experiment Approach (SEA) Terhadap Hasil Belajar IPA Siswa Kelas V SD Gugus II Kecamatan Banjar, Kabupaten Buleleng Tahun Pelajaran 2017/2018".

Berdasarkan hal tersebut maka di gunakan sebuah pembelajaran yaitu"Starter Experiment Approach (SEA) (Suastra, 2013:150) merupakan pendekatan komprehensif dalam pembelajaran sains. SEA sebagai sebuah pendekatan pembelajaran dalam sains berorientasi kepada proses bagaimana siswa dapat menemukan konsep-konsep sains yang sedang dipelajari siswa, proses dimaksud mencakup aspek kognitif". Menurut Sudana (2016:61) "SEA sebagai pendekatan pembelajaran IPA mengikuti tahapan-tahapan metode ilmiah yang meliputi pengamatan, perumusan masalah, pengajuan dugaan, pengujian dugaan, perumusan konsep dan penerapan konsep"

Secara prinsip Starter Experiment Approach (SEA) merupakan pendekatan pembelajaran yang menghubungkan IPA menjadi materi ajar di sekolah dengan IPA yang dialami atau disaksikan oleh siswa dalam kehidupan sehari-hari. Penggunaan Starter Experiment Approach (SEA) dalam pembelajaran memberikan kesempatan kepada siswa untuk merumuskan sendiri pengetahuan yang dipelajarinya. Hal ini terjadi mulai dari kegiatan pengamatan hingga percobaan yang dilakukan untuk membuktikan hipotesisnya.

Menurut Hasil peneliti yang dilakukan oleh Cahyani (2015) berdasarkan hasil analisis data dan pembahasan dapat ditarik simpulan sebagai berikut. Terdapat perbedaan yang signifikan hasil belajar IPA antara kelompok siswa yang belajar menggunakan model pembelajaran starter eksperimen berbantuan peta konsep dengan kelompok siswa yang belajar menggunakan model pembelajaran konvensional pada siswa kelas $\mathrm{V}$ tahun pelajaran 2014/2015 di SD Gugus Tambora Kecamatan Melaya (thit=2,927 > ttab=2,021).

Dari uraian tersebut, maka permasalahan yang dapat dirumuskan yaitu apakah terdapat pengaruh yang signifikan Starter Experiment Approach (SEA) Terhadap Hasil Belajar IPA Siswa Kelas V SD Gugus II Kecamatan Banjar Kbaupaten Buleleng Tahun Pelajaran 2017/2018?

Berdasarkan masalah yang telah dirumuskan, maka tujuan penelitian ini adalah untuk mengetahui Pengaruh Starter Experiment Approach (SEA) Terhadap Hsil Belajar IPA Siswa Kelas V SD Gugus II Kecamatan Banjar Kabupaten Buleleng Tahun Pelajaran 2017/2018. 


\section{Metode}

Adapun tempat pelaksanaan penelitian ini adalah di Gugus II Kecamatan Banjar, Kabupaten Buleleng Tahun Pelajaran 2017/2018.Penelitian ini adalah penelitian eksperimen.Mengingat tidak semua variabel dan kondisi eksperimen dapat diatur dan dikontrol secara ketat, maka penelitian ini dikategorikan penelitian semu (quasi experiment). Rancangan yang digunakan pada penelitian ini adalah nonequivalent post-test only control group design. Populasi dalam penelitian ini adalah keseluruhan kelas V SD yang ada di Gugus II Kecamatan Banjar Kabupaten Buleleng.Sebelum menetapkan sampel, terlebih dahulu dilakukan uji kesetaraan hasil belajar IPA siswa berupa hasil UTS IPA semester ganjil siswa kelas V SD di Gugus II Kecamatan Banjar Kabupaten Buleleng.Untuk mengetahui apakah kemampuan masing-masing siswa kelas $\mathrm{V}$ di SD setara atau belum.Untuk mengetahui tingkat kesetaraan tersebut terhadap populasi sampel dalam penelitian ini dilakukan uji kesetaraan dengan menggunakan Anava satu jalur.

Berdasarkan analisis data, diperoleh nilai Fhitung $=1,50$ sedangkan nilai Ftabel pada taraf signifikansi 5\% dengan dbantar $=3$ dan dbdal $=105$ adalah 2,69. Ini berarti Fhitung lebih kecil daripada Ftabel yang berarti pula Fhitung tidak signifikan. Dengan demikian berarti $\mathrm{HO}$ yang menyatakan tidak terdapat perbedaan yang signifikan antara hasil belajar IPA siswa kelas V SD di Gugus II Kecamatan Banjar Kabupaten Buleleng diterima.Jadi dapat disimpulkan bahwa tidak terdapat perbedaan yang signifikan antara hasil belajar IPA siswa kelas V SD di Gugus II Kecamatan Banjar Kabupaten Buleleng. Dengan kata lain, hasil belajar IPA siswa kelas V SD di Gugus II Kecamatan Banjar Kabupaten Buleleng adalah relatif sama atau setara.

Sampel adalah "sebagian dari populasi yang diambil, yang dianggap mewakili seluruh populasi dan diambil dengan menggunakan teknik tertentu" (dalam Agung, 2014:69).Sampel tersebut diambil dengan teknik tertentu. Sampel pada penelitian ini diambil dengan cara undian (random sampling). Cara untuk mengambil sampel penelitian adalah sebagai berikut.Masingmasing kelas $\mathrm{V}$ tiap sekolah diberi nomor urut, selanjutnya dipilih dua kelas secara random untuk dijadikan sampel. Untuk menentukan kelas eksperimen dan kelas kontrol digunakan dengan cara undian (random sampling). Kemudian dua sekolah yang terpilih yaitu SD N 4 Temukus sebagai kelas eksperimen yang mendapat perlakuan Starter Experiment Approach (SEA). Sedangkan kelas kontrol SD N 5 Temukus yang tidak mendapat perlakuan Starter Experiment Approach (SEA).

Instrumen Penelitian disusun sebelum pengumpulan data.Pengumpulan instrumen penelitian bertujuan agar saat menerapkan metode penelitian dapat memperoleh data yang lebih baik.Dalam penelitian ini data yang diperoleh adalah data tentang hasil belajar IPA siswa, yang terbentuk soal pilihan ganda sebanyak 30 soal. Sebelum tes digunakan untuk mengambil data hasil belajar IPA terlebih dahulu instrumen di uji cobakan untuk mengetahui validitas, reliabilitas, tingkat kesukaran, dan daya beda. Kepada 60 siswa kelas VI di SD Gugus II Kecamatan Banjar Kabupaten Buleleng sebagai responden.Tekhnik analisis data yang digunakan yaitu analisis statistik deskripstif dan analisis statistik inferensial. (uji-t). Sebelum menguji hipotesis dengan uji-t, terlebih dahulu data diuji normalitasnya menggunakan rumus chi-kuadrat dan uji homogenitas varians dengan menggunakan uji $F$.

\section{Hasil dan Pembahasan}

Rangkuman hasil belajar IPA dari 23 siswa kelompok eksperimen dan 23 siswa kelompok kontrol dapat dilihat pada Tabel 2 dan berikut ini 
Tabel 2. Ringkasan Perhitungan Mean, Median, Modus, Standar Deviasi, dan Varians

\begin{tabular}{ccc} 
Data Statistik & Kelompok Eksperimen & Kelompok Kontrol \\
\hline Mean & 22,96 & 16,57 \\
\hline Median & 23,01 & 15,87 \\
\hline Modus & 23,79 & 14,25 \\
\hline Varians & 8,45 & 16,22 \\
\hline Standar Deviasi & 2,91 & 4.03
\end{tabular}

Untuk lebih memahami Tabel berikut maka dibuatkanlah dalam kurva poligon padagambar 1 kelompok eksperimen berikut ini.

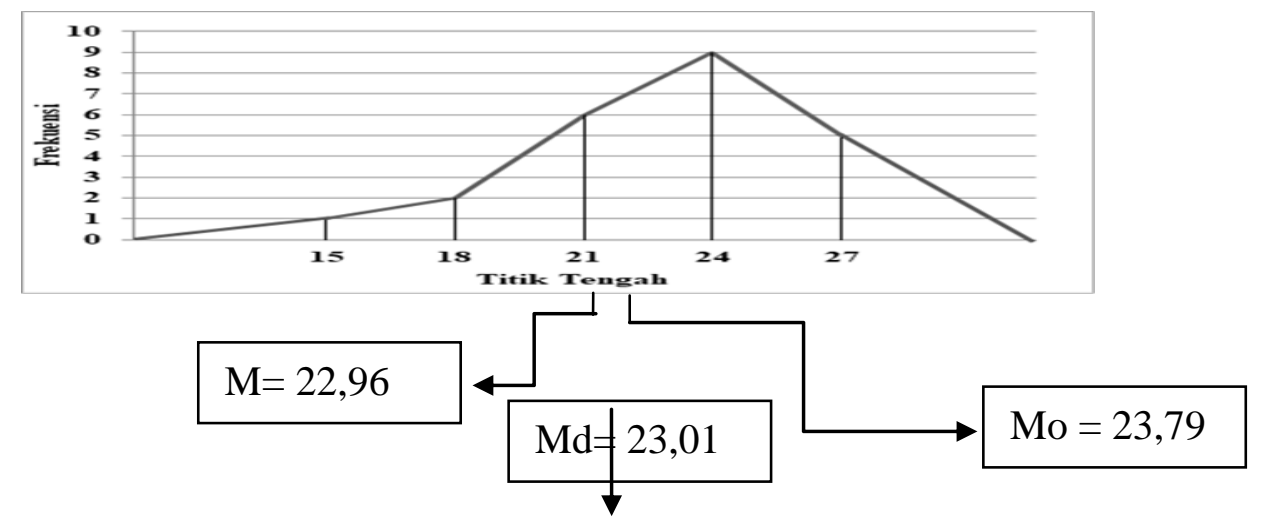

Gambar 1. Kurva Poligon Data Hasil Belajar IPA Kelas Eksperimen

Dari hasil kurva poligon data hasil belajar IPA kelas eksperimen di atas, dapat diketahui bahwa modus lebih besar dari median dan median lebih besar dari mean ( $\mathrm{MO}>\mathrm{Md}>\mathrm{M})$. Dengan kata lain, kurva di atas adalah kurva juling negatif. Artinya, sebagian besar skor cenderung tinggi.Kecenderungan skor ini dapat dibuktikan dengan melihat frekuensi relatif pada tabel distribusi frekuensi.Frekuensi relatif skor yang berada di atas rata-rata lebih besar dibandingkan frekuensi relatif skor yang berada di bawah rata-rata.

Selanjutnya untuk kelas kontrol disajikan kurva poligon pada gambar 2 berikut ini.

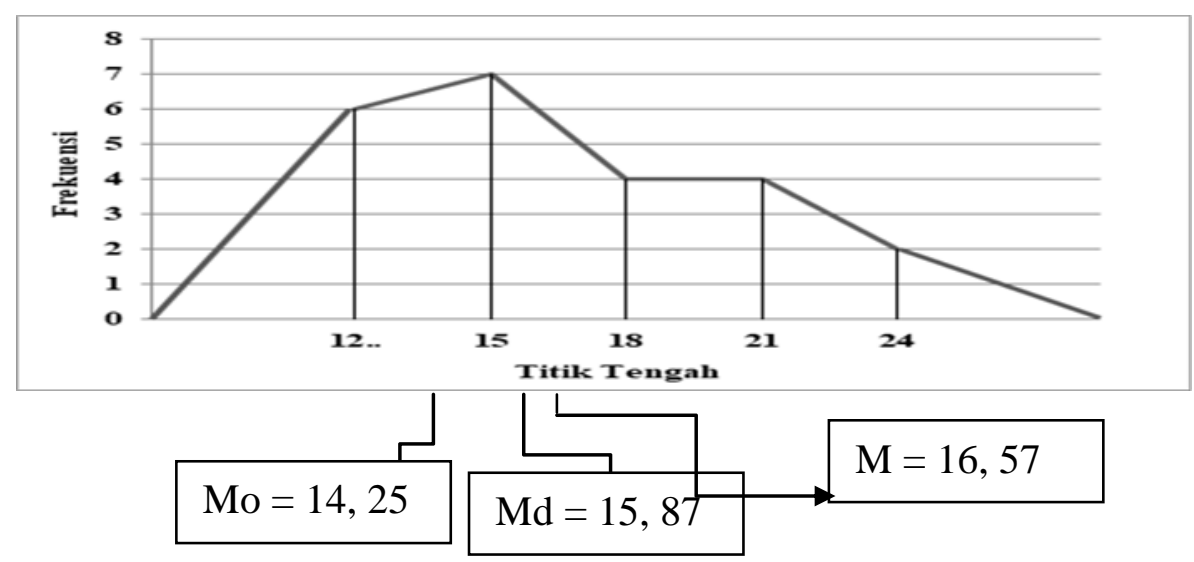

Gambar 2. Kurva Poligon Data Hasil Belajar Kelas Kontrol

Dari hasil kurva poligon data hasil belajar kelas kontrol di atas, dapat diketahui bahwa modus lebih kecil dari median, dan median lebih kecil dari mean. $(\mathrm{MO}<\mathrm{Md}<\mathrm{M})$. Dengan kata 
lain, kurva diatas adalah kurva juling positif. Artinya, sebagian besar skor cenderung rendah.Kecenderungan skor ini dapat dibuktikan dengan melihat frekuensi relatif pada tabel distribusi frekuensi.Frekuensi relatif skor yang berada di atas rata-rata lebih kecil dibandingkan frekuensi relatif skor yang berada di bawah rata-rata.Selanjutnya akan dibahas ringkasan hasil uji normalitas kelompok eksperimen dan kelompok kontrol pada Tabel 3 berikut ini.

Tabel 3. Ringkasan Hasil Uji Normalitas Kelomok Eksperimen dan Kelompok Kontrol

\begin{tabular}{clccc}
\hline No & Sampel Penelitian & $\mathrm{X}^{2}$ & $\begin{array}{c}\text { Nilai Kritis dengan taraf } \\
\text { signifikansi 5\% }\end{array}$ & Status \\
\hline 1 & Kelompok Eksperimen & 2,819 & 5,591 & Normal \\
2 & Kelompok Kontrol & 2,964 & 5,591 & Normal \\
\hline
\end{tabular}

Dari Tabel 3 di atas menunjukkan bahwa kelompok eksperimen nilai $X^{2}{ }_{\text {hitung }}(2,819)$ berada di bawah $\mathrm{X}^{2}$ tabel $(5,591)$ untuk statistik Chi-Kuadrat. Berdasarkan kriteria uji normalitas, data berdistribusi normal jika $X^{2}{ }_{\text {hitung }}$ lebih kecil daripada $X^{2}$ tabel. Dengan simpulan maka data kelompok eksperimen berdistribusi normal.Sedangkan kelompok kontrol nilai $X^{2}{ }_{\text {hitung }}(2,964)$ berada di bawah $\mathrm{X}^{2}$ tabel $(5,591)$ untuk statistik Chi-Kuadrat. Berdasarkan kriteria uji normalitas, data berdistribusi normal jika $X^{2}{ }_{\text {nitung }}$ lebih kecil daripada $X^{2}$ tabel. Dengan simpulan maka data kelompok kontrol berdistribusi normal.

Selanjutnya menghitung uji homogenitas dengan cara memasangkan varians dari kelompok eksperimen dan varians dari kelompok kontrol. Uji yang digunakan adalah uji-F. Berdasarkan hasil perhitungan bahwa uji homogenitas $F_{\text {hitung }}$ sebesar 1,92 dan $F_{\text {tabel }}$ sebesar 2,05 dengan taraf signifikansi 5\%. Dari ketentuan bahwa jika $F_{\text {hitung }}<F_{\text {tabel }}$ maka data dinyatakan homogen. Jadi dari data yang diperoleh tersebut dinyatakan bahwa $F_{\text {hitung }}(1,92)<$ $F_{\text {tabel }}(2,05)$ maka data dinyatakan homogen.

Setelah mencari kehomogenan data maka dilanjutkan dengan memasukan rumus ke dalam uji t. Analisis uji t pada data kelompok eksperimen dan kelompok kontrol tersebut digunakan separated varians dengan $n_{1}=23$, dan $n_{2}=23$ pada Tabel 4 berikut ini.

Tabel 4. Hasil Uji t.

\begin{tabular}{|c|c|c|c|c|c|}
\hline Kelompok & $\mathrm{N}$ & Varians & $t_{\text {hitung }}$ & $t_{\text {tabel }}$ & Simpulan \\
\hline Eksperimen & 23 & 8,45 & 6,14 & 2,07 & Siginifikan \\
\hline Kontrol & 23 & 16,22 & & & \\
\hline
\end{tabular}

Dari ringkasan data di atas dinyatakan bahwa $t_{\text {hitung }}$ sebesar 6,14 dan $t_{\text {tabel }}$ sebesar 2,07 dengan taraf signifikansi $5 \%$. Dengan kriteria $t_{\text {hitung }}>t_{\text {tabel }}$ maka uji $t$ dengan menggunakan separated varians dikatakan signifikan. Maka analisis dengan uji t dari hasil kelompok eksperimen dan kelompok kontrol adalah $t_{\text {nitung }}(6,14)>t_{\text {tabel }}(2,07)$ pada taraf signifikansi $5 \%$, maka data tersebut ditarik simpulannya yaitu signifikan. Jadi dapat diketahui bahwa $t_{\text {hitung }}>t_{\text {tabel, }}$, maka $\mathrm{H}_{0}$ ditolak dan $\mathrm{H}_{1}$ diterima. Artinya, terdapat pengaruh yang signifikan hasil belajar IPA antara kelompok siswa yang dibelajarkan dengan menggunakan starter experiment approach (sea) dan kelompok siswa yang dibelajarkan tidak menggunakan starter experiment approach (sea) pada siswa kelas V SD Gugus II Kecamatan Banjar Kabupaten Buleleng Tahun Pelajaran 2017/2018.

Dari analisis data hasil belajar IPA menunjukkan bahwa terdapat adanya perbedaan dengan siswa kelas eksperimen dan siswa kelas kontrol. Ini berarti pada siswa kelas eksperimen mendapat perlakuan dengan penerapan pembelajaran starter experiment approach (sea), sedangkan siswa pada kelas kontrol tidak diberikan perlakuan berupa penerapan pembelajaran starter experiment approach (sea) pada siswa kelas V SD di Gugus II Kecamatan Banjar Kabupaten Buleleng Tahun Pelajaran 2017/2018. Hal ini didasari dari ratarata skor hasil belajar IPA siswa dan dari perhitungan hasil pengujian uji-t. Berdasarkan rata- 
rata skor hasil belajar dari kelompok eksperimen yang di berikan perlakuan pembelajaran Starter Experiment Approach (SEA) adalah sebesar 22,96. Sedangkan rata-rata skor hasil belajar IPA pada siswa kelompok kontrol yang tidak menggunakan perlakuan Starter Eksperiment Approach (SEA) adalah sebesar 16,57. Dengan demikian hasil analisis data menggunakan uji-t diperoleh $t_{\text {hitung }}$ sebesar 6,14 dan $t_{\text {tabel }}$ sebesar 2,07 dengan taraf signifikansi $5 \%$. Dari perhitungan tersebut menyatakan bahwa $t_{\text {hitung }}>t_{\text {tabel }}$, sehingga $\mathrm{HO}$ ditolak dan $\mathrm{H} 1$ diterima. Dengan adanya pengaruh yang signifikan tersebut menyatakan bahwa pembelajaran Starter Experiment Approach (SEA) berpengaruh pada hasil belajar IPA siswa kelas V SD di Gugus II Kecamatan Banjar Kabupaten Buleleng Tahun Pelajaran 2017/2018.

Perbedaan hasil belajar IPA antara kelompok siswa yang diberikan perlakuan dengan pembelajaran Starter Experiment Approach (SEA) dan kelompok siswa yang tidak diberikan perlakuan dengan pembelajaran Starter Experiment Approach (SEA) disebabkan oleh perbedaan langkah-langkah proses pembelajaran.

Dari pembelajaran Starter Experiment Approach (SEA) siswa memiliki kesempatan untuk lebih aktif dalam proses menemukan sendiri pengetahuan yang sedang dipelajarinya. Siswa dapat melakukan partisipasi secara aktif dalam kegiatan pengamatan, merumuskan masalah, dugaan sementara, tahap pengujian, perumusan konsep, penerapan konsep, serta evaluasi.Dari hal tersebut seiring dengan teori belajar sosial yang dikemukakan oleh Albert Bandura yang memaparkan bahwa belajar pada dasarnya adalah upaya kreatif individu dalam menemukan pengetahuan dan mengembangkan struktur pengetahuannya dalam berinteraksi dengan lingkungan (Hergenhahn, B.R. dan Matthew H. Olson, 2008). Temuan dalam penelitian ini juga didukung oleh penelitian yang dilaksanakan oleh Nyeneng (2015) ia mengadakan penelitian yang berjudul Pengaruh Model Pendekatan Starter Eksperimen (PSE) Terhadap Keterampilan Proses Sains dan Hasil Belajar Sains Siswa SD Gugus VIII Kecamatan Abang. Hasil Penelitian ini menunjukkan bahwa Pendekatan Starter Eksperimen dalam pembelajaran sains dapat meningkatkan keterampilan proses sains dan hasil belajar sains siswa.

Pembelajaran dengan Starter Experiment Approach (SEA) diawali dengan melakukan percobaan yang dilakukan oleh guru, sebagai contoh percobaan awal, dan siswa yang lain melakukan pengamatan sesuai dengan percobaan awal yang telah dilakukan oleh guru di depan kelas. Berdasarkan hal tersebut, maka siswa memiliki kebenaran faktual karena kebenaran tersebut diamati secara langsung oleh siswa dan di praktekan oleh guru itu sendiri di depan kelas. Dari hal tersebut seiring dengan teori perkembangan kognitif yang dikemukakan oleh Piaget yang memaparkan bahwa anak usia sekolah dasar (7-11 tahun) berada pada tahap kongkrit operasional. Pada periode ini seorang anak mulai memperoleh tambahan kemampuan yang disebut satuan langkah berpikir (system operation) yang berfungsi untuk mengkoordinasikan pemikiran dan idenya dengan peristiwa tertentu ke dalam sistem pemikirannya sendiri sehingga ia mampu mengambil keputusan yang logis. (Suwatra, 2015:53) Dalam penggunaan panca indra dalam proses belajar akan memberikan keyakinan terhadap materi ajar akan menjadi lebih mudah dan dapat terselesaikan dengan baik. Setelah proses pengamatan, dilanjutkan dalam tahap merumuskan masalah, dalam merumuskan masalah guru dapat membantu siswa untuk merumuskan dugaan sementara. Pada tahap dugaan sementara ini siswa dapat mengajukan dugaannya terhadap masalah yang dirumuskan secara bebas. Berdasarkan hal tersebut, mengakibatkan adanya perbedaan pemahaman antara siswa yang satu dengan siswa yang lain mengenai perumusan dugaan sementara yang diajukan oleh siswa. Pada tahap pengujian atau verifikasi siswa melakukan percobaan pengujian disusun untuk membuktikan dugaan sementara dari masalah yang telah dirumsukan. Mencakup hal tersebut, maka pada saat proses melakukan percobaan pengujian siswa dituntut untuk berfikir kreatif serta mampu mengembangkan keterampilan-keterampilan proses IPA, peserta didik akan mampu menemukan dan mengembangkan fakta dan konsep serta menumbuhkan sikap dan nilai yang dituntut. Dengan demikian siswa akan menemukan sendiri pemahaman serta penguasaan yang sesuai dengan hasil yang diperoleh selama proses pembelajaran yang pada gilirannya akan dapat meningkatkan kualitas pembelajaran. Hal ini didukung oleh teori belajar penemuan menurut Bruner (Suwatra, 2015:37) yang menyatakan bahwa belajar penemuan pada akhirnya dapat meningkatkan penalaran dan kemampuan untuk berpikir secara bebas 
dan melatih keterampilan kognitif siswa dengan cara menemukan dan memecahkan masalah yang ditemui dengan pengetahuan yang telah dimiliki dan menghasilkan pengetahuan yang benar-benar bermakna. Pada tahap perumusan konsep siswa merumuskan konsep berdasarkan atas percobaan pengujian yang telah dilakukan oleh siswa tersebut. Hal ini sejalan dengan teori Piaget yang menyatakan bahwa penyusunan pengetahuan ini disusun menurut jenis-jenis pengalaman yang ada pada diri si belajar (Suwatra, 2015:51). Pada tahap penerapan konsep, siswa memperoleh dari berbagai situasi lain dan faktor ini akan mencerminkan siswa apakah siswa tersebut mampu memberikan indikasi bahwa siswa telah memahami konsep secara komprehensif. Tahap akhir yaitu evaluasi, pada tahap ini siswa mampu untuk menunjukkan tingkat pemahaman siswa atas konsep yang telah diperolehnya.

Berbeda halnya dengan kelompok kontrol yang tidak menggunakan penerapan Starter Experiment Approach (SEA). Dalam proses pembelajaran lebih menekankan pada penyampaian pengetahuan tanpa mengaitkan dengan kehidupan sehari-hari. Guru menyampaikan materi dengan proses pembelajaran ceramah, tanya jawab dan mencatat apa yang disampaikan oleh guru di depan kelas. Dalam hal ini, siswa hanya berperan sebagai pendengar dan mengerjakan apa yang disuruh oleh guru. Pembelajaran seperti ini membuat siswa memiliki pengetahuan yang kurang bermakna karena pengetahuan yang dimilikinya hanya ditransfer dari guru itu sendiri. Hal ini senada dengan Rasana, (2009:21) pengetahuan yang kurang bermakna akan lebih mudah terlupakan sehingga akan berpengaruh terhadap hasil belajar siswa itu sendiri. Hasil penelitian ini sesuai dengan beberapa penelitian tentang penerapan Starter Experiment Approach (SEA). Penelitian yang dilakukan Cahyani (2015) yang berjudul Pengaruh Model Pembelajaran Starter Eksperimen Berbantuan Peta Konsep Terhadap Hasil Belajar IPA Siswa Kelas V SD. Hasil penelitian menunjukkan bahwa Starter Eksperimen dapat meningkatkan hasil belajar IPA siswa SD.

Berdasarkan pemaparan di atas, dapat disimpulkan bahwa terdapat pengaruh yang signifikan hasil belajar IPA siswa yang mengikuti pembelajaran dengan menerapkan Starter Experiment Approach (SEA) pada siswa kelas V di sekolah dasar Gugus II Kecamatan Banjar Kabupaten Buleleng Tahun Pelajaran 2017/2018.Dengan demikian, Starter Experiment Approach (SEA) berpengaruh terhadap hasil belajar IPA siswa

\section{Simpulan dan Saran}

Berdasarkan rumusan masalah dan hasil penelitian di atas maka, dapat disimpulkan bahwa terdapat pengaruh Starter Experiment Approach (SEA) terhadap hasil belajar IPA antara siswa kelas $\mathrm{V}$ yang mendapat perlakuan pembelajaran Starter Experiment Approach (SEA) dan siswa kelas $\mathrm{V}$ yang tidak mendapat perlakuan pembelajaran Starter Experiment Approach (SEA) di Gugus II Kecamatan Banjar Kabupaten Buleleng tahun pelajaran 2017/2018. Berdasarkan hasil uji hipotesis dengan uji-t diperoleh nilai thitung sebesar 6,14dan ttabel sebesar 2,07(dengan taraf signifikansi 5\%). Hasil analisis menunjukkan bahwa thitung lebih besar daripada ttabelyaitu6,14> 2,07 sehingga $\mathrm{H} 0$ ditolak dan $\mathrm{H} 1$ diterima. Disamping itu, rata-rata skor hasil belajar IPA siswa kelas $\mathrm{V}$ yang mendapat perlakuan pembelajaran Starter Experiment Approach (SEA) $(22,96)$ lebih tinggi daripada rata-rata skor hasil belajar IPA siswa kelas $\mathrm{V}$ yang tidak mendapat perlakuan pembelajaran Starter Experiment Approach (SEA) $(16,57)$.

\section{Daftar Pustaka}

Agung,A. A. Gede. 2014. Metodologi Penelitian Pendidikan. Malang: Aditya Media Publishing.

Bundu, Ratta. 2006. Penilaian Keterampilan Proses dan Sikap IImiah dalam Pembelajaran Sains Sekolah Dasar. Departemen Pendidikan Nasional. 
Cahyani, Novita. 2015. Pengaruh Model Pembelajaran Starter Eksperimen Berbantuan Peta Konsep Terhadap Hasil Belajar IPA Siswa Kelas V. Jurnal Universitas Pendidikan Ganesha, Volume 3.

Dewi. 2013. "Pengaruh Model Pembelajaran Kuantum Berbantuan Media Video Kontekstual terhadap Hasil Belajar IPA". Singaraja: Undiksha.

Lestari, Sri. 2012. Meningkatkan Penguasaan Konsep Fisika dengan Melibatkan Kemampuan Analisis Sintesis, Kemampuan Numerik Siswa melalui Pembelajaran dengan Pendekatan Starter Eksperiment Approach (SEA). Tesis. Yogyakarta: Universitas Ahmad Dahlan.

Lestari, Sri. Meningkatkan Kemampuan Pemecahan Masalah Fisika Kelas Xi lis 1 Sma Muhammadiyah 2 Yogyakarta Melalui Pembelajaran Sea (Starter Experiment Approach). Jurnal IImiah Guru “COPE”, No. 02/Tahun XIX/November 2015

Nyeneng, I Ketut. 2015. Pengaruh Model Pendekatan Starter Eksperiment (PSE) Terhadap Keterampilan Proses SAINS dan Hasil Belajar SAINS Siswa SD Gugus VIII Kecamatan Abang. Jurnal Universitas Pendidikan Ganesha, Volume 5.

Mirah. 2012. "Implementasi Pendekatan Starter Eksperimen (Starter Experiment Approach) Untuk Meningkatkan Minat dan Hasil Belajar IPA". Singaraja: Undiksha

Purwanto. 2009. Evaluasi Hasil Belajar. Yogyakarta: Pustaka Pelajar

Samatowa, Usman. 2010. Pembelajaran IPA di Sekolah Dasar. Jakarta: PT Indeks

Saputra, Pt. Andi, I Md. Tegeh, I Wyn. Widiana. 2017. Pengaruh Pendekatan Starter Eksperimen (Starter Experiment Approach) Berbantuan Video Terhadap Hasil Belajar Ipa Kelas V. e-Journal PGSD Universitas Pendidikan Ganesha Mimbar PGSD Vol: 5 No: 2.

Suastra, Wayan. 2013. Pembelajaran Sains Terkini. Singaraja: Undiksha

Sudana, Dewa dan Kusmariyatni. 2016. Pendidikan IPA SD. Singaraja: Undiksha

Suwatra, dkk. 2015. Belajar dan Pembelajaran Sekolah Dasar. Singaraja: Universitas Pendidikan Ganesha.

Utami. 2012. "Implementasi Pendekatan Starter Eksperimen Untuk Meningkatkan Hasil Belajar IPA". Singaraja: Undiksha. 